Institute for December, 1873, vol. iii.). The phosphatised material, which forms stalagmitic layers at the side of and interstratified with the other deposits, is leaden-grey in colour, weathering light brown outside, friable, and full of small holes. Portions of it yielded, on analysis, a large per-centage of phosphate of lime.

It is not probable that these deposits were thrown down in a phosphatised condition, as they occur also unphosphatised.

The beds in which they are found were in places largely made up of the bones of small birds, mammals, etc., which, as Prof. Hughes has shown, are chiefly the remains of the pellets of owls and kestrels; feathers and skin occurring in the upper, but none in the lower part of the deposit. The only apparent way in which it seems that the travertine could have become phosphatised is by the percolation of water through the pellet bed, until it was stopped by the stalagmite, which would slowly absorb the water, and allow time for the chemical reactions which resulted in the phosphatising of a portion of it.

A somewhat similar instance is noticed by Prof. Dana "Coral and Coral Islands," p. 293), who states that a deposit of guano on Howland's Island has been the means of phosphatising fragments of coral which have somehow become included in its mass. Similarly at Caylus phosphatised matter occurs associated with the bones themselves; but in the case of Cave Ha no such matter occurs in the deposits in which the bones are found, but only in the travertine surrounding and associated with the bones.

\title{
INOTICES OF MEIMOIRS.
}

\section{I.-The Antrquity of Mav, Iluustrated by the Contents of} Caves and the Relics of the Cave-folk. By Prof. T. Rupert Jones, F.R.S., F.G.S. ${ }^{1}$

DROFESSOR Rupert Jones introduced his subject by reminding his hearers that antiquaries can trace back the successive periods of governments and dynasties by the relics and ruins beneath London, from the Georgian to the Roman age. He referred to Colonel Lane Fox's discovery of an old pile-village of the Romano-British pariahs in the Finsbury marsh, and to the indications of still older aboriginal wattled huts in pit-dwellings on the gravel subsoil beneath Panl's Cross, in Cheapside. The fossil contents of this gravel, under various parts of London, lead us further back in time beyond the historic and pre-historic ages to what geologists term the "post-Tertiary period," when the Thames, much wider than now, formed great shoals of gravelly shingle, and wide-spread flats of loamy floodmud, and drifted away the carcasses of mammoth, rhinoceros, lion, urus, musk-ox, and other animals now strange to the district. The relics of man, such as implements of stone, are found here and there, with the bones of these Pleistocene animals in the valleygravels of the Thames and its tributaries; also in similar gravels in

1 Being the substance of a Lecture delivered to the Croydon Microscopical Club, on Wednesday evening, April 26th, 1876, in the Public Hall ; Henry Lee, Esq., F.L.S., F.G.S., etc., President of the Club, in the Chair. 
neighbouring valleys, both in England and France, and in the caves of limestone districts, where similar conditions existed. The subsequent decrease of the river, leaving its terraced margins of gravel and loam, and the ultimate coating of peat over the marshy flats bordering its now narrow channel, complete the history of the changes down to the historic period. In these later river-deposits, and in the peat-bogs, implements of polished stone, of bronze, and of iron, are found to have been successively deposited; but in the older gravels and associated loams, whether in the valleys or in the caves, stone implements (shaped only by chipping) are found, and, as the oldest kind, have given the name "Palzolithic" to their period; whilst the subsequent age, when man had got the habit of sharpening his weapons of stone by grinding, is termed "Neolithic." The great lapse of time required to complete the formation of the Danish peat-bogs, in which implements of iron, bronze, and polished stone are successively accompanied by the beech of the present period, the older oak, and the still more ancient fir tree, belonging to three changes of conditions, and of the associated animal life, was next dwelt upon. An account of the Swiss lake-dwellings, or pile-villages, was then given; and the indications of successive generations or peoples, using iron, bronze, and polished stone tools, in more or less distinct gradations, were pointed out. Those using implements of stone were not altogether uncivilized; and yet, if the incomplete evidence of geographical changes be accepted, they lived some 6000 years before the Roman conquest of Western Europe. They did not possess the reindeer, though that animal had been hunted near by in earlier times by cave-dwellers (Canton Schaffhausen), and in France; and then the climate must have been cold enough for its existence so far south, and cold enough for the hahitation of rock-shelters on sunny slopes, where during the present summers of France, even for the stench-bearing Esquimaux to abide, with the heaps of garbage, stinking flesh and bones, would have been impossible; but there, the hunters of the reindeer, horse, and musk-ox, did live, using chipped flint tools, and knowing not how to grind and polish them-though they used some kinds of grindstones in preparing food and paint, and were artistically inclined. They cleverly engraved outlines of animals and otluer things on bone, ivory, and stone, with pointed flints, and shaped bone and ivory into handles of poniards and quaint statuettes. Among their drawings is a lively figure of the hairy high-fronted elephant (Mammoth), which they therefore must have seen, and which ranged over the colder regions of the western hemisphere. The long and unknown space of time requisite for the change of climate from Arctic conditions in South France and Switzerland to warmer winters and hotter summers, unfavourable to the existence of mammoth, reindeer, and musk-ox, divided the cave-dwellers, using chipped flakes, from the lake-dwellers, using polished stone implements. These cave-folk of Dordogne and elsewhere, however, were by no means the oldest inhabitants of caves. They lived at or near the level of existing rivers; but there are caves containing relics of 
human inhabitants, which have been left high up in the limestone cliffs, whilst the rivers have worn away the gorge below to a great depth (nearly $300 \mathrm{ft}$. at Gailenreuth ; $75 \mathrm{ft}$. at Brixham). This is shown by the presence of certain pebbles in the deposits within the cave, which must have rolled across the interval, from the other side of the valley, whilst a floor existed at a level of the cave. If this excavation be due to the violent rush of the torrent from the increased slope of its channel, caused by the rising of the land, what was the rate of elevation? Further, some few of the caves contain stone implements of ruder make than those left in others; and the valley-gravels left behind as terraces and isolated patches by the rivers, which have deepened and narrowed their channels, also contain such rude and even ruder implements, carefully, after all, but roughly chipped, and doubtless serving very well the purpose to which these early people applied them. 'These gravels contain remains of the Arctic animals. Their age is to be reckoned by the time required for their formation and their distribution. The subsequent excavation of lower valleys, and the other stages of time already indicated, necessarily lengthen their chronology. Their existence is owing to the early formation of gravel-flats and plains of loam out of the débris of the land, when it was far above its present height; and when Western Europe had been raised so high out of water as to comprise the British Islands as far as the wellknown "hundred-fathom-line," which when raised to the waterlevel would of course add at least $600 \mathrm{ft}$. to the height of the land's surface. The Alps were much higher than now; and probably Snowdon stood at least $2000 \mathrm{ft}$. higlier than at present. This elevation originated in the great alteration of the earth's crust in this portion of the globe by contraction, immediately after the long "Tertiary Period" of geologists, bringing in the new conditions of geography, hydrography, and distribution of life in what is known as the "post-Tertiary Period." The great uprise of land was probably slow; it introduced enormous glaciers, grooving out great gorges, which, after vast and continuous changes, the greatest rivers have scarcely yet filled up with their plain-making detritus. Whether men existed or not in this earliest part of the Quaternary period is as yet unproved. A great reaction took place, and a great and gradual subsidence lowered plain and mountain, until Snowdon sank to be an island not more than $1000 \mathrm{ft}$. at most in height, and the shoulders of the momtain were below the great northern sea; for, when it rose again, Moel Tryfaen (now $1300 \mathrm{ft}$. above the sea) bore up the well-known sands and shingle with marine shells, in witness of the change. Man had set foot in this region by that time; for when the glaciers, during some of their oscillations, occupied the great vales of Western Yorkshire, one of them left some of the characteristic laminated mud in a cave opening against its lateral moraine, and this mud buried up some old cave-earth, in which are bunes of elephant, rhinoceros, hippopotamus, hyæna, and man. This glacial clay was surmounted by a cave-earth formed after the glacier had melted away and left the valley open but cold, for reindeer bones 
occur in this layer. Subsequently the face of the cliff slowly shed its frost-bitten fragments, and formed a talus of great thickness, on the slope of which Neolithic men came and went. Then after some 500 years (as measured by the rate of formation of the talus), the Romano-British (or Brit-welsh), driven from their cities by invaders (Picts or Saxon), lodged in the cave, and left their relics on the sunny slope outside; and these are covered by the fallen screes of 1200 years. Add these small sums of historic and pre-historic years together; allow for the period of reindeer life in Yorkshire; measure out a time for the glacier's coming and going; and add the many years and ages whilst the great Pleistocene animals roamed over the changing scene, and some notion will be gained of the antiquity of man. To allow for the last uprise of Snowdon, for its previous subsidence, and still earlier and higher elevation, some 200,000 years at least is required, when the glacial period came in. If not before this period, certainly during some part of the time, whilst England was continuous with the Continent, the mammoth and man existed here together; and the many great changes that have occurred since Palæolithic man left his implements in lakes, rivers, and caves, have required a large proportion of those 2000 centuries.

II.-Results of Observations on the Eskers, Lake-basivs, and Post-Glactal River-cocrses of Cheshire, Shropsuire,

- Denbighshire, and Flintshire, with Remiris on the Sequence of Glacial Events in the N.W. of England and Wales. By D. Mackintosh, F.G.S.

[Read before the Chester Society of Natural Science, Feb. 3, 1876.]

THHE Chester Society of Natural Science, which was established 1 several years ago by the late Rev. Charles Kingsley, now numbers between five and six hundred members. The above paper is the second that has been printed. In it the author begins by giving an account of the drifts between Chester, Gresford, and Wrexham, with a particular reference to the sudden change of level exhibited by the upper or brick-clay between Pulford and Gresford, a change nearly 200 feet in vertical extent. The lower Boulderclay in this neighbourhood is either confined to patches or represented by an angular rocky rubble called "rammel." The author then goes on to describe the distribution of Eskers in Caernarvonshire, Glyn Ceiriog, upper valley of the Dee, around Gresford, Gwersyllt, Cefn-y-bedd, Padeswood, Mold, Nannerch, Caerwys, Flint, Oakmere (east side of Delamere Forest), Beeston Castle, Combermere, Baschurch, Oswestry, and especially around Ellesmere. The author then enters into a particular consideration of the causes which determined the positions of eskers, laying great stress on the influence of projecting rocks, etc. The curvilinear forms of esker knolls, and especially of the enclosed hollows, he attributes to both the depositing and denuding action of eddying tidal currents. A more detailed account is then given of the high-level eskers on Halkin mountain, which contain fragments of sea-shells, and one of 
which is a perched esker, 950 feet above the sea-level ; of " a very striking array of gigantic eskers" between Bodfari and Mold, a number of which on or near to a watershed reach a height of between 120 and 150 feet, and which often rise at an angle of $45^{\circ}$; of the eskers enclosing swamp-and lake-basins near Gresford, and around Ellesmere. The latter are often as abrupt as artificial earthworks, and rise to a height of quite 150 feet above the very beautiful and pellucid sheets of water which repose in the intermediate hollows. These eskers and lake-basins form quite a feature on the Ordnance map. A few of them are capped with clay. After considering the causes of the retention of water in the esker hollows (which generally appear to consist of sand or fine gravel), and preferring the theory that "the decay of vegetation artificially planted or naturally grown in the basins may have increasingly acted as a retainer of water," the author proceeds to assign reasons for regarding the forms of post-glacial river-courses "as the effect of unequal deposition, tidal scour, and freshwater floods." Among mountains near the sources of drift-supply, valleys were often filled up to a certain height with drift extending uniformly and continuously across; but in the greater part of the district described in the paper, the filling up of the valleys (according to the author) must have been very partial and unequal, so that the rivers, generally speaking, found ready-made channels after the final emergence of the land. "In many places the denudation (effected by the rivers) would amount to cutting a slice out of the side of one knoll, and leaving a knoll or drift-slope on the other side of the valley unscathed, or it would take the form of a lateral encroachment on a knoll or slope, so as to leave either a straight or horseshoe-shaped cliff-line, the opposite side of the valley still retaining the shape given to it by the sea." After supporting his ideas by referring to phenomena in the courses of the Dee, Alyn, and Ceiriog, in Morecambe Bay, the estuary of the Mersey, the pits in the Irish Sea, English Channel, etc., the author concludes with the following general account of the north-west of England and Wales:- "I believe this area includes a variety of phenomena which are more calculated than those of any other British area to suggest the true sequence of glacial and interglacial events. Within a small compass it embraces plains, wide and narrow valleys, cwms, lakes, tablelands, groups and ranges of mountains, and neighbouring sea-beds. In ascending order it contains, (1st) pre-glacial white clay and sand; (2nd) two if not three kinds of lower boulder-drift which in different districts go under the names of rammel (ground moraine of Mr. Mellard Reade), blue clink, pinnel or sammel, in addition to a shelly lower boulder-clay; (3rd) coarse esker-gravel-and-sand of hilly or adjacent districts; (4th) fine sand and gravel of low-level plains; (5th) upper boulder or brick-clay. Southward the area under consideration graduates into a non-glacial district. Northwards it graduates into the Lake District, and westwards into the Snowdonian and Merionethshire Districts, in both of which are to be found the sure signs of great sheets of land-ice and glaciers-namely, 
groups of dome-shaped rocks or roches moutonnées, often crossing stratification and cleavage, showing smoothly-rounded and striated up-stream, and jagged down-stream or lee sides, and occurring at both low and high levels. In the boulder-clay of the plains the intensely glaciated stones (more so than I have seen or heard of in any other part of the British Isles) bear witness (as I have elsewhere endeavoured to show) to the action of floating ice. There are numerous and widespread indications of the transportation of boulders across mountain-ranges and drainage-areas, and to distances probably not paralleled in any other part of the British Islands. In some of the upland cwms and valleys there are perhaps the best defined supra-glacial moraines to be met with anywhere else in the kingdom." This is followed by a statement of the newest opinions at which the author has arrived concerning the general sequence of glacial and interglacial events. ${ }^{\mathbf{1}}$

\section{REPOETS AND PROCFEDINGS.}

Geological Society of London.-T.-April 5, 1876.-Prof. P. Martin Duncan, M.B., F.R.S., President, in the Chair. The following communications were read :-

1. "The Bone-caves of Creswell Crags."-Second paper. By the Rev. J. Magens Mello, M.A., F.G.S.

In this paper the author gives an account of the continuation of his researches upon the contents of the caves in Creswell Crags, Derbyshire. The further exploration of the Pin Hole Cave described in his former paper ${ }^{2}$ furnished a few bones of Reindeer, Rhinoceros tichorhinus, and other animals, but no more remains of the Arctic Fox, which were particularly sought for. Operations in this cave were stopped because the red sand in which the bones were found towards the entrance became filled with limestone fragments, and almost barren of organic remains. The author then commenced the examination of a chambered cave called Robin Hood's Cave, situated a little lower down the ravine on the same side. The section of the contents of this cave showed a small thickness of dark surface-soil, containing fragments of Roman and Medirval pottery, a human incisor, and bones of sheep and other recent animals; over a considerable portion a hard limestone breccia, varying in thickness from a few inches to about three feet; beneath this a deposit of lightcoloured cave-earth, varying in thickness inversely to the breccia, overlying a dark-red sand about three feet thick, like that of the $\mathrm{Pin}$ Hole, but with patches of laminated red clay near the base, and containing scattered nodules of black oxide of manganese, and some quartzite and other pebbles, which rested upon a bed of lightercoloured sands containing blocks of limestone, probably forming part of the original floor of the cavern. The hard stalagmitic

1 For Articles on Drift-deposits by Mr. Mackintosh, see Geol. Mag. for Oct. and Dec., 1870; Feb., June, and July, 1871; Jan. and Sept., 1872; Feb., 1874 ; etc.

2 See Quart. Journ. Geol. Soc. vol. хxxi. p. 679. 